Kamil Sobczak (Łódź)

\title{
Transition FROM THE TEMPLE OF JUPITER TO THE Great Mosque of Damascus IN ARCHITECTURE AND DESIGN
}

$\mathrm{T}$ The Great Mosque of Damascus is one of the most important buildings in the Islamic world. It was built between 705 and 715 by the Umayyad Caliph al-Walid I. However, the origins of this building date to the distant past. At first it was a location of an ancient Aramaean temple dedicated to the god Hadad. After the successful military campaign of Alexander the Great and with the forthcoming Hellenization the temple was dedicated to Zeus. In the first century BC Romans transformed it into a temple of Jupiter (Iupiter Damascenus). With the dawn of Christianity in the Roman Empire, Emperor Theodosius in 391 converted the temple into the Cathedral of Saint John. The last stage of transformation was an Umayyad Mosque, which was rebuilt many times because of renovations after natural disasters. Listed phases reveal how complex the history of this sacred area is. The main goal of this article is to signalize the main changes that took place within that space in order to determine how deep in the past is it possible to search for an architectural correlation. Furthermore, it seems important to answer whether they had an impact on the later Islamic architecture through the Umayyad Mosque.

As far as the structures erected before the mosque are concerned, their history seems to be parallel to the history of Damascus, which should be presented cursorily. Damascus is located between Mount Qasiyun on the west and the desert in the east, in a fertile oasis supplied by water from the river Barada. The earliest findings which suggest habitation of this region date back to $9000 \mathrm{BC}^{1}$. Nevertheless, there is a lack of signs suggesting vast and developed settlements in the oasis. Even so, excavations in Syria have revealed complex settlements, which have been dated back to $9600 \mathrm{BC}^{2}$. Traces of urbanization were dated during excavation to the fourth millennium BC. Different sources mostly mention Damascus during the time of the Amorites, Hittites and Egyptians taking control over the area ${ }^{3}$.

\footnotetext{
${ }^{1}$ R. Burns, Damascus: A History, Abingdon 2007, p. 2.

2 B. Arnaud, Firs Farmers, Archeo 53, 2000, p. 56-59.

${ }^{3}$ Clay tablet at Ebla mentioned Damascus ( $3^{\text {rd }}$ millennium BC). Egyptian hieroglyphic tablets mention the city among other conquest of pharaoh Thotmes III in 1490 BC. Cf.: R. BURNs, op. cit., p. 5-7.
} 
Furthermore, there are references in the Bible $e^{4}$ and in Antiquitates Judaicae by Joseph Flavius 5 . With the end of the Bronze Age, development of the region was disturbed by a migration of the so-called People of the Sea ${ }^{6}$. Damascus become an important city in the Near East thanks to Aramaeans in the first millennium BC. Due to the adoption of the Phoenician alphabet, the Aramaic language, spread within the Near East after Damascus became part of the Assyrian Empire in the eighth century BC. With Assyrian rule Aramaic (or rather the Imperial Aramaic) become a regional lingua franca. That Aramaic however, was different from its precursor $^{7}$. Later on, the city was controlled first by Babylonians and Persians respectively in the seventh and sixth century $\mathrm{BC}^{8}$. However, the main changes in the city's appearance must be connected with Alexander the Great and his conquest of Syria in 333 BC. Damascus came under the strong influence of Hellenization and was transformed considerably under the regime of the Seleucids ${ }^{9}$. In 90 BC the city might have been reestablished as Demetrius ${ }^{10}$. After a successful campaign in the Near East, Pompey the Great created the Roman Province of Syria in 64 BC $^{11}$. Then Damascus became one of ten cities of the Decapolis ${ }^{12}$. In the fourth century CE Christianization took place in all of Syria. After the end of the unified Roman Empire in $395 \mathrm{CE}$, the city became an important part of the eastern (Byzantine) Empire up to the year $635 \mathrm{CE}$ when it was finally conquered by Muslims ${ }^{13}$. Under the rule of the Umayyad dynasty, Damascus flourished as a new capital of the Caliphate ${ }^{14}$.

This historical summary gives a necessary background for describing changes that took place within the sacred area located in the center of Damascus. As there are no previous traces, the first archaeologically perceptible stage is the temple

\footnotetext{
${ }^{4}$ Gn 14,15 .

${ }^{5}$ Josephus Flavius, Antiquitates Judaicae, I, 6, 4, I, 7, 2, [in:] Dawne dzieje Izraela, trans. Z. KuBIAK, J. RADOŻYCKI, Warszawa 2001.

${ }^{6}$ J. Śliwa, Sztuka i archeologia starożytnego Wschodu, Warszawa-Kraków 1997, p. 194-195.

${ }^{7}$ S. PARPola, National and Ethnic Identity in the Neo-Assyrian Empire and Assyrian Identity in PostEmpire Times, JAAS 18, 2004, p. 6-22.

${ }^{8}$ J.M. MilLer, Syria: Land of Civilizations, NEA 64, 2001, p. 122-131.

${ }^{9}$ R. BuRns, op. cit., p. 37.

${ }^{10}$ Discussion over placement of the city Demetrius and its founder Demetrius III was described by G.M. Cohen. Cf.: G.M. Cohen, The Hellenistic Settlements in Syria, the Red Sea Basin, and North Africa, Berkeley-Los Angeles-London 2006, p. 242-245.

${ }^{11}$ W. Ball, Rome in the East: The Transformation of an Empire, London-New York 2002, p. 62.

${ }^{12}$ Gaius Plinius Secundus, Naturalis Historiae, V, 16, 74., [in:] Historia naturalna, trans. I. ZAWADZKa, T. ZAWADZKI, Wrocław-Kraków 1960.

${ }^{13}$ B. CесотA, Ekspansja arabska na tereny bizantyńskie (632-718) oraz początki organizacji kalifatu, [in:] Bizancjum i Arabowie. Spotkanie cywilizacji, VI-VIII wiek, ed. T. WolıńsKa, P. Filipczak, Warszawa 2015, p. 300.

${ }^{14}$ N. KHALeK, Damascus after the Muslim Conquest: Text and Image in Early Islam, Oxford 2011, passim.
} 
of Hadad ${ }^{15}$. The Semitic god Hadad was the head of the Aramaic pantheon in the ninth century $\mathrm{BC}^{16}$. Among many attributes, he was primarily the god of thunderstorms and rain, and it seems that as such a deity he was worshipped in high places ${ }^{17}$. Strongly connected with a bull as a symbol, he was usually depicted with horns or as an anthropometrical animal ${ }^{18}$. Such an important deity required a suitable place of worship. The sacred area which had been chosen for this enterprise is the same on which the Umayyad Mosque stands today. Unfortunately, there is almost no data concerning this structure. The only surviving piece of the temple is an orthostat with a bas-relief depicting a sphinx, found at the northern wall of the mosque (now in the Damascus National Museum) ${ }^{19}$. Nevertheless, some conclusions may be drawn. As for the construction of the temple we might expect a strong Phoenician influence ${ }^{20}$ as it was in the case of the First Temple of Jerusalem, which would be a suitable comparison ${ }^{21}$. The temple of Hadad presumably had the shape of an elongated rectangle with a walled courtyard. As typical for Phoenician architecture, the elevation of consecutive chambers is expected ${ }^{22}$. It might be also connected with the type of deity, as the storm god should be worshipped on a high place ${ }^{23}$. We have no further information concerning the temple. Even though Damascus was conquered many times, the sacred area seems to play an important religious role, up to the Seleucid rule in the city without any major breaks.

In the second century BC Damascus started to became a more Hellenistic city thanks to the stability provided by Antiochus the Great and his successors. At that time, transition from Hadad into the Greek equivalent of Zeus began to be noticeable $^{24}$. The temple became a major point in the new urbanization system based on the Hippodamean plan. The entrance to the temple was located at the east and was

\footnotetext{
${ }^{15}$ Mentioned in the Bible, 2 Reg 5,18; Cf.: R. Dussaud, Le Temple de Jupiter Damascénien et ses transformations aux époques chrétienne et musulmane, Sy 3, 1922, p. 219.

${ }^{16}$ J.C. Greenfield, Hadad, [in:] Dictionary of Deities and Demons in the Bible, ed. K. van DeR Toorn, B. Becking, P.W. van Der Horst, Leiden-Boston-Koln 1999, p. 377-382.

${ }^{17}$ R. Burns, op. cit., p. 38.

${ }^{18}$ I. SKupiŃsKA-LøvSET, Kulty na et-Tell. Źródła archeologiczne, SBO 3, 2011, p. 109-125.

${ }^{19}$ E. Djafar Abd el-Kader, Un orthostate du temple de Hadad à Damas, Sy 26, 1949, p. 191-195.

${ }^{20}$ Hadad was a known and worshiped deity in the Phoenician cities, cf.: J.C. GreEnfield, op. cit., p. 381. Furthermore, the orthostat found during excavations was created in a Phoenician style E. DJAfar AbD el-Kader, op. cit., p. 193-194.

${ }^{21}$ The First Temple of Jerusalem was built by Phoenician architects and craftsman, J. ŚLIwA, op. cit., p. 216; other argument for the Phoenician influence is mentioned earlier Aramaic language itself, with its alphabet adopted from Phoenicia, S. PARpola, op. cit., passim.

${ }^{22}$ Typical as well to Egyptian architecture, which had a great influence on the Phoenician one, cf.: J. ŚliwA, op. cit., p. 216.

${ }^{23}$ R. BuRns, op. cit, p. 40. In Bethsaida (et-Tell) the worship of Hadad is located within the city gate complex and not in the temple. I. SKUPIŃsKa-LøvsET, op. cit., p. 110-111.

${ }^{24}$ R. Burns, op. cit., p. 40.
} 
connected with the agora by a Via Sacra. Nevertheless, the architectural character was still a Semitic one, only partially fitted with Greek elements like temenos (inner courtyard) or cella/naos (inner chamber) ${ }^{25}$. The whole premise had to be relatively vast as it was later reused by the Romans in the erection of the temple of Jupiter. Attribution of the temple to Jupiter seems natural because of his huge similarity to Zeus. The Roman construction was one of the largest in the Near East, and significantly rearranged the previous plan $^{26}$. Its history became known due to the elementary research over the history of Damascus and the Umayyad Mosque, that started at the end of the eighteenth century $\mathrm{CE}$ and lasted until the beginning of the twentieth century $\mathrm{CE}^{27}$. It was later supplemented by the further research. Studies led to the identification of Roman architectural remains among city buildings, which lie in the vicinity of the Umayyad Mosque, with the temple of Jupiter ${ }^{28}$. The main structure of the temple was assembled from a peribolos (outer courtyard) with dimensions of $380 \times 310 \mathrm{~m}$ and a temenos with dimensions of $156 \times 97 \mathrm{~m}$ (Fig. 1a). The temenos was erected probably during the regime of August in the first century BC; the peribolos was finished later, in the middle of the first century $\mathrm{CE}$. One of the last major improvements and renovations was made during the rule of Emperor Septimius Severus in the second century $\mathrm{CE}^{29}$. The wall of the temenos was built from ashlar blocks. Every corner of the structure had a square tower. Erection of the towers might have been motivated by the dedication to Jupiter, with the high superstructures no longer needed for the religious purposes ${ }^{30}$. There was an entrance on each side of the temple. The main entrance was placed at the east wall of the temenos and was leading to a cella. The external size of the complex was determined by a colonnade in the Corinthian architectural order. Formed that way, the peribolos had also a lay usage as a market place or festival area, which was not something unusual in the ancient Near East ${ }^{31}$. The colonnade provided perfect protection against sun and rain. There is still an ongoing debate regarding

\footnotetext{
${ }^{25}$ C. Watzinger, K. Wulzinger, Damaskus. Die antike Stadt (Wissenschaftliche Veröffentlichungen des deutsch-türkischen Denkmalschutz-Kommandos, Berlin-Leipzig 1921, p. 62-64.

${ }^{26}$ K.S. Freyberger, Untersuchungen zur Baugeschichte des Jupiter-Heiligtums in Damasku, DMi 4, 1989 p. 61-86.

${ }^{27}$ Research over ancient Damascus were strongly connected with its political status in the last four centuries. Therefore, studies were mostly conducted by British and French expeditions. The German and then French research at the beginning of the $20^{\text {th }}$ century, confirmed previous suspicions that the structure of the ancient temple of Jupiter lies within the permit of the Umayyad Mosque and city structure. Cf.: C. Watzinger, K. Wulzinger, op. cit., passim; R. Dussaud, op. cit., p. 219-250.

${ }^{28}$ C. WATZinger, K. Wulzinger, op. cit., p. 62.

${ }^{29}$ The remains of the outer colonnade, which might be found at the present Damascus are dated back to renovation by Septimius Severus.

${ }^{30}$ The towers were probably used for sacrificial practices. Cf.: R. BuRns, op. cit., p. 89.

${ }^{31}$ One of the most famous example comes of the Bible when "Cleansing of the Temple" took place as traders and bankers were cast out from the Temple. Mt 21,12-27, Mc 11,15-33, and Lc 19,45-48, 20,1-8, Io 2,13-16.
} 
the origins of such a vast construction ${ }^{32}$. The collaboration of the High Priest and the local aristocracy seems the most appealing, as a strictly Roman undertaking is highly unlikely at that time. As a good example, enterprises of Herod the Great should be taken into consideration. The process took place at the same time in the Near East under Roman influence ${ }^{33}$ and was financed by the king himself. However, the situation is analogous only partially as Damascus was under a different administrative order. Thus, differences are highly probable.

The next important moment came in the fourth century CE, when Christianity became the main religion in the Roman Empire. Emperor Theodosius in 391 converted the temenos ${ }^{34}$ of the temple into the Christian Cathedral of Saint John. The reason for that attribution is a legend regarding the head of Saint John the Baptist being buried in the temple (commemorated later by a shrine built inside the Umayyad Mosque ${ }^{35}$. Unfortunately, because of the final transition into a mosque (as the church was destroyed) there is no certain data regarding the shape and situation of the Christian structure ${ }^{36}$. The church probably stood in the center or in the southern-west corner of the temenos, however, there is no indisputable evidence (Fig. 1b-c). Different locations might be a result of different approach to the Roman and Christian temples ${ }^{37}$. Moreover, the smaller scale is the most probable as there are no other sources regarding the church being so immense. It is worth mentioning, that after the conquest of Damascus in 635 the temenos was used as a prayer space by Muslims. The situation changed in 705 when the Umayyad Caliph al-Walid I decided to definitively replace the church with the mosque.

The new structure was ready in 715. The Umayyad Mosque is especially interesting for the Byzantine influence on its architecture and decor. The construction of the building is based solely on the Roman basilica. The choice of the basilica as a structural model might have been motivated by the size of previous structures and requirements of religious practices. As the choice of the place might have been based on political and religious factors, it had strong repercussions on the new construction. The temenos was a big structure and the building within it also had to rise to a huge size ${ }^{38}$. The Islamic practice of praying in the direction to Mecca

\footnotetext{
${ }^{32}$ R. BurNs, op. cit., p. 89.

${ }^{33}$ R.L. Hohlfelder, Beyond Coincidence? Marcus Agrippa and King Herod's Harbor, JNES 59, 2000, p. 241-253.

${ }^{34}$ While the peribolos role as a part of the temple become less important and was incorporated within market (at the west and north side) and later contained by palace (at the south-east side).

${ }^{35}$ Attribution to Saint John the Baptist is problematic as evidence suggest that it stated no sooner than the $6^{\text {th }}$ century CE and might be strongly connected with the promotion of the legend by Christians and Muslims as well. Cf.: R. Burns, op. cit, p. 89, 282.

${ }^{36}$ Ibidem, p. 89.

${ }^{37}$ L. cit.

${ }^{38}$ Size of the Great Mosque exceeded the demands of not so vast at that time Muslim community, cf.: F.B. Flood, The Great Mosque of Damascus: Studies on the Makings of an Umayyad Visual Culture, Leiden 2001, p. 235.
} 
(location of the qibla wall) was another factor for rearrangement ${ }^{39}$. The Umayyad Mosque was thus built on the south side of the building leaving the rest of the temenos as an open courtyard (Fig. 1d). The main structure was different from the typical Roman basilicae as it had three aisles of an unusual even size on an east-west line and one aisle on a north-south line across the middle of the structure. The aisles were formed by the arched columns, some of which might been reused in the church and belonged originally to the Roman Temple. The roof over the transept was topped with a dome flanked by two half-domes. This element was also copied from Byzantine architecture ${ }^{40}$. It was destroyed in a fire in 1401 and rebuilt later without the half-domes. As the temenos walls did not have windows there was trouble with a lack of daylight inside. The solution was a wooden roof with tiles, built high enough to create a space for windows. It is worth noting, that this feature became very typical for Islamic architecture. A new entrance to the mosque was located at the northern wall. Applied arches and the construction of a façade were purely Byzantine ${ }^{41}$. Decoration and mosaics created by Byzantine craftsmen had a huge impact on further buildings in Egypt and Levant ${ }^{42}$. Even after thirteenth century when Mameluks had risen to power, art motifs were copied into their architecture ${ }^{43}$. The temenos towers were used as a base for the erection of minarets.

The Great Mosque of Damascus become a pattern for Islamic architecture of the Umayyads and their successors ${ }^{44}$. Therefore, purely Roman/Byzantine elements became ubiquitous in the Islamic world. The Umayyad Mosque is not only an architectural phenomenon. Behind the visible changes in building, and its decoration, stands the continuity of the sacred space. There are many factors that should be taken into consideration about this process, from strictly religious and social reasons, to economic and political factors. Nonetheless, the fact is that the Semitic cult of Hadad was replaced by a Greco-Roman one. The polytheistic religions were then substituted by Christianity, which in the case of Damascus was eventually dominated by Islam in the seventh century. That kind of transition was not an isolated example in the Near East. One of the most well known is the Dome

\footnotetext{
${ }^{39}$ R. BuRns, op. cit., p. 115.

${ }^{40}$ Flood had suggested that inspiration for the dome was Hagia Sophia as Caliph al-Walid I would have thought that the conquest of Constantinople was unavoidable and had huge ambitions regarding this aim. Cf.: F.B. Flood, The Great Mosque..., p. 163-164.

${ }^{41}$ Remarkable resemblance to the $6^{\text {th }}$ century Theoderics palace in Ravenna, which façade is known from the mosaics of Basilica di Sant'Apollinare Nuovo in Ravenna. Cf.: F.B. Flood, The Great..., p. 163. ${ }^{42}$ F.B. Flood, Umayyad Survivals and Mamluk Revivals: Qalawunid Architecture and the Great Mosque of Damascus, Muq 14, 1997, p. 57-79.

${ }^{43}$ Ibidem, p. 57.

${ }^{44}$ Ibidem, passim; Grafman and Rosen-Ayalon had suggested that as Umayyad Mosque was definitely an inspiration for Islamic architecture, however, at least the same role or even bigger played the Dome of the Rock in Jerusalem. Cf.: R. Grafman, M. Rosen-Ayalon, The Two Great Syrian Umayyad Mosques: Jerusalem and Damascus, Muq 16, 1999, p. 1-15.
} 
of the Rock in Jerusalem. Moreover, it has been recorded that the same process took place in Damascus, in the case of the Umayyad Mosque ${ }^{45}$. The Great Mosque of Damascus, however, might have taken the continuity even further. A retraceable and confirmed transition is only from the Roman temple into the Mosque (with a Christian church stage). Roman/Byzantine patterns and the reuse of previous design were listed above. However, another question arises, whether it is possible to look for traces of patterns further in the past to Aramaic and Assyrian architecture. Taking into consideration the case of high places, there are indications that could lead to a continuity of sacred space from such a distant past. High places were used for sacrificial purposes and recreation of them within the Hellenistic temple as towers, might have been motivated by easing religious transition ${ }^{46}$. Furthermore, when the Mosque was built they were incorporated as bases for minarets. The origin of minaret and the reason for the building of such constructions is a complicated merit in itself ${ }^{47}$. The Umayyad Mosque with its minarets undoubtedly had a huge impact on Islamic architecture. It needs to be underlined that such course of events as proposed here can only be considered as theoretical. One of the main reasons for that is the fact that the archaeological excavation within such sacred areas, especially while still in use, is very difficult. The core of archaeological data regarding previous stages of the Great Mosque comes from excavation conducted at the beginning of the twentieth century ${ }^{48}$. There are a lot of factors regarding changes within the sacred space in Damascus. Some of them are simply impossible to recreate and at this point we can try to find correlations in architecture by comparison with different archaeological sites. Nonetheless, based on Creswell's view regarding the towers of the Temple of Jupiter and the origin of minarets, it is plausible to make hypothetical connections with previous constructions. Creswell had suggested that towers of the Temple of Jupiter, used by Muslims just before the erection of the Great Mosque, might have been an inspiration for building those kind of structures as minarets (the first ones) in the mosque located in Fustat by the Umayyad governor of Egypt. Not long later minarets were built in the Great Mosque. Leaning on that theory, it would be possible to search for the origins of the Great Mosque of Damascus not only in the Temple of Jupiter, but even in the Aramaic temple from the tenth century BC.

\footnotetext{
${ }^{45}$ A. Bounni, Du Temple païen à la Mosquée: note préliminaire sur le cas de la Mosquée Omeyyade de Damas, [in:] Sacralidad y Arqueología, Antigüedad y Cristianismo XXI, ed. A. GonzÁlez Blanco, J.M. BLÁzQues MartíneZ, Murcia 2004, p. 595-605.

${ }^{46}$ As Hadad and Zeus has comparable features usage of these similarities by combining rituals seems to be appealing.

${ }^{47} \mathrm{~K}$. CReswell, The evolution of the minaret, with special reference to Egypt, BMag 48, 1926, p. 134-140; J.M. BLoom, Creswell and the Origins of the Minaret, Muq 8, 1991, p. 55-56.

${ }^{48}$ Therefore, almost every research regarding the earliest stages of this sacred area are based on the work of German expedition, which because of political and financial reasons had been conducted very fast and without standards of modern archaeology.
} 


\section{Bibliography}

\section{Sources}

Gaius Plinius Secundus, Naturalis Historiae, [in:] Historia naturalna, trans. I. Zawadzka, T. ZAWADZKI, Wrocław-Kraków 1960.

Josephus Flavius, Antiquitates Judaicae, [in:] Dawne dzieje Izraela, trans. Z. Kubiak, J. RadoŻYCKI, Warszawa 2001.

\section{Secondary literature}

Arnaud B., Firs Farmers, Archeo 53, 2000, p. 56-59.

Ball W., Rome in the East: The Transformation of an Empire, London-New York 2002.

Bloom J.M., Creswell and the Origins of the Minaret, Muq 8, 1991, p. 55-58.

Bounn A., Du Temple païen à la Mosquée: note préliminaire sur le cas de la Mosquée Omeyyade de Damas, [in:] Sacralidad y Arqueología, Antigüedad y Cristianismo XXI, ed. A. GonZÁlEz BLANco, J.M. Blázques Martínez, Murcia 2004, p. 595-605.

Burns R., Damascus: A History, Abingdon 2007.

Сесота B., Ekspansja arabska na tereny bizantyńskie (632-718) oraz poczatki organizacji kalifatu, [in:] Bizancjum i Arabowie. Spotkanie cywilizacji, VI-VIII wiek, ed. T. WolińsKa, P. Filipczak, Warszawa 2015, p. 298-345.

Cohen G.M., The Hellenistic Settlements in Syria, the Red Sea Basin, and North Africa, Berkeley-Los Angeles-London 2006.

Creswell K., The evolution of the minaret, with special reference to Egypt, BMag 48, 1926, p.134-140.

DjAfar AbD El-Kader, E., Un orthostate du temple de Hadad à Damas, Sy 26, 1949, p. 191-195.

Dussaud R., Le Temple de Jupiter Damascénien et ses transformations aux époques chrétienne et musulmane, Sy 3, 1922, p. 219-250.

Flood F.B., The Great Mosque of Damascus: Studies on the Makings of an Umayyad Visual Culture, Leiden 2001.

Flood F.B., Umayyad Survivals and Mamluk Revivals: Qalawunid Architecture and the Great Mosque of Damascus, Muq 14, 1997, p. 57-79.

Freyberger K.S., Untersuchungen zur Baugeschichte des Jupiter-Heiligtums in Damasku, DMi 4, 1989, p. 61-86.

Grafman R., Rosen-Ayalon M., The Two Great Syrian Umayyad Mosques: Jerusalem and Damascus, Muq 16, 1999, p.1-15.

Greenfield J.C., Hadad, [in:] Dictionary of Deities and Demons in the Bible, ed. K. van Der Toorn, B. Becking, P.W. van der Horst, Leiden-Boston-Koln 1999, p. 377-382.

Hohlfelder R.L., Beyond Coincidence? Marcus Agrippa and King Herod's Harbor, JNES 59, 2000, p. 241-253.

Khalek N., Damascus after the Muslim Conquest: Text and Image in Early Islam, Oxford 2011.

MilLer J.M., Syria: Land of Civilizations, NEA 64, 2001, p. 122-131.

Parpola S., National and Ethnic Identity in the Neo-Assyrian Empire and Assyrian Identity in PostEmpire Times, JAAS 18, 2004, p. 6-22. 
SKupiŃska-Løvset I., Kulty na et-Tell. Źródła archeologiczne, SBO 3, 2011, p. 109-125.

Śliwa J., Sztuka i archeologia starożytnego Wschodu, Warszawa-Kraków 1997.

Watzinger, C., Wulzinger K., Damaskus. Die antike Stadt (Wissenschaftliche Veröffentlichungen des deutsch-türkischen Denkmalschutz-Kommandos), Berlin-Leipzig 1921.

\begin{abstract}
Great Mosque of Damascus was built between 705 and 715 by the Umayyad Caliph al-Walid I. However, the origins of this building dates to the distant past. At first it was a location of an ancient Aramaean temple dedicated to the god Hadad. With Hellenization the temple was dedicated to Zeus and in the first century BC the Romans transformation it into the Temple of Jupiter Damascenus. In 391 Emperor Theodosius converted the temple into Christian Cathedral of Saint John. Erection of the mosque by Caliph al-Walid I was under strong influence of earlier constructions. Meaning and consequences of such transitions, from the Roman temple (there is almost no data of the Aramaic building) through the Christian Cathedral to the Islamic mosque is an interesting process. Issue not only within the art and architecture, but what is more, in a religious aspect of the continuity of sacred space.
\end{abstract}

Keywords: Hadad, Temple of Jupiter Damascenus, Great Mosque of Damascus, Roman architecture, Islamic architecture.

Kamil Sobczak

Instytut Archeologii Uniwersytetu Łódzkiego

ul. Uniwersytecka 3

90-137 Łódź, Polska/Poland kamelmestre@gmail.com 
a
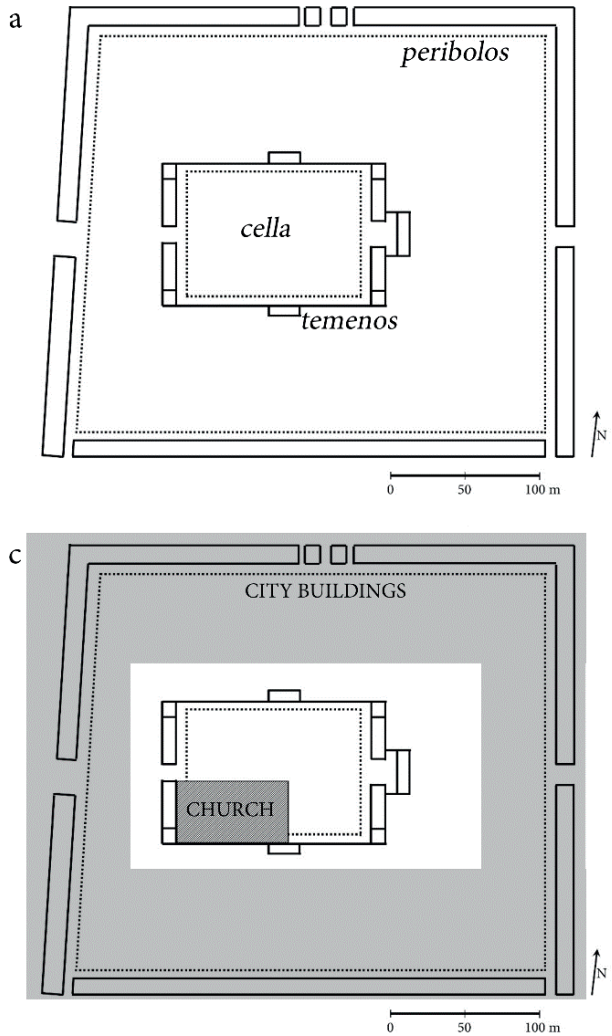

b

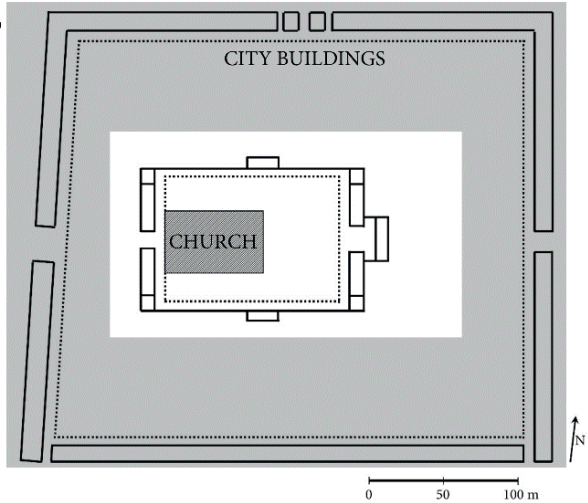

$\mathrm{d}$

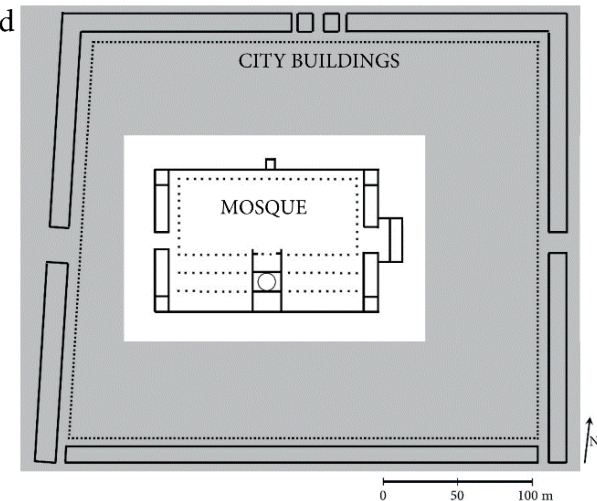

Fig. 1. Simplified plan of transformation based on research of Watzinger and Wulzinger: a) Temple of Jupiter, b) Cathedra of Saint John the Baptist located at the center (beginning of the city buildings extension) c) Cathedra of Saint John the Baptist located at the south-west corner (beginning of the city buildings extension), d) The Great Mosque of Damascus 